\title{
Algılanan Kurumsal Sosyal Sorumluluğun Satın Alma Niyeti Üzerindeki Etkisinde Güvenin Aracılık Rolü
}

\author{
Aslı Tolunay Kuşçu a, b, Burçak Vatansever Durmaz c, Merve Koçoğlu Sazkaya ${ }^{d}$
}

\section{Özet}

İşletmeler kâr elde etme amaciyla kurulmuş olsalar da topluma karşı yerine getirmeleri gereken sorumlulukları vardır. Bir başka deyişle, toplum işletmelerden belli başlı sorumlulukları gerçekleştirmelerini beklemektedir. $\mathrm{Bu}$ bağlamda, işletmeler sosyal sorumluluk projeleri gerçekleştirerek müşterilerinin beklentilerini karşılama eğilimindedirler. Diğer taraftan, işletmeler yapmış oldukları sosyal sorumluluk projeleri çerçevesinde müşterilerin güvenini kazanarak satın alma davranışlarını etkilemeyi de amaçlamaktadırlar. Dolayısıyla, bu çalışmanın amacı müşterilerin sosyal sorumluluk algılarının satın alma niyeti üzerindeki etkisinde güvenin aracılık rolünü incelemektir. Bahsi geçen kavramlar arasındaki ilişkiyi tespit etmek amacıyla araştırma, bir vakıf üniversitesinde yüksek lisans eğitimi alan 313 kişi üzerinde gerçekleştirilmiştir. Araştırmada Türkiye otomotiv pazarında bilinen lider bir firma üzerinden sorular sorulmuş olup araştırma sonuçları, algılanan sosyal sorumluluğun satın alma niyeti üzerindeki etkisinde güvenin tam aracı etkisi olduğunu göstermekte ve güvenin önemini vurgulamaktadır.
Anahtar Kelimeler

Algilana Kurumsal Sosyal

Sorumluluk

Satın Alma Niyeti

Güven

Otomotiv Sektörü

Makale Hakkında

Geliş Tarihi: 10.02.2019

Kabul Tarihi: 20.11.2019

Doi: $10.18026 /$ cbayarsos.525188

\section{Mediating Role of Trust on the Relationship between Perceived Corporate Social Responsibility and Purchase Intention}

\begin{abstract}
Although organizations are founded to gain profit, they also have responsibilities towards the society. In other words, individuals expect from the organizations to accomplish some major responsibilities towards the society.In this respect, organizations try to respond to that call by doing various social acts that will create beneficial outcomes for the overall society. On the hand, organizations also aim to shape consumers' purchasing behavior by gaining trust through these activities. Therefore, this study investigates the mediating role of trust within the relationship between perceived social responsibility and purchase intention. With this aim, 313 graduate students of a private university were approached to collect data and to analyze the proposed relationships between the constructs. Data have been collected by mentioning a well-known market leader car manufacturer and results of the study indicate that trust fully mediates the relationship between perceived corporate social responsibility and purchase intention, thus emphasizing the importance of trust in company-consumer relationships.
\end{abstract}

Keywords

Perceived Corporate Social

Responsibility

Purchase Intention

Trust

Automotive Sector

About Article

Received: 10.02 .2019

Accepted: 20.11.2019

Doi: 10.18026/cbayarsos.525188

\footnotetext{
a İletişim Yazarı: asli.kuscu@yahoo.com

b Dr. Öğr. Üyesi, Yeditepe Üniversitesi İsletme Bölümü, İstanbul, 0000-0003-3856-8518

c Dr. Öğr. Üyesi, Bahçeşehir Üniversitesi Sosyal Bilimler Enstitüsü, İstanbul, 0000-0001-8940-0761

d Doç. Dr., Marmara Üniversitesi İşletme Fakültesi Yönetim Organizasyon Anabilim Dalı, İstanbul, 0000-0002-4820-8092
} 


\section{Giriş}

Günümüzde müşterilerin, işletmelerin sunmuş olduğu ürün ve hizmeti değerlendirirken, kalite, fiyat, marka imajı, toplumsal beğeni gibi kriterlerin yanı sıra işletmelerin tüm paydaşlarına sunduğu imkânları değerlendirerek satın alma kararlarını verdikleri görülmektedir. Örneğin, işletmelerin sosyal sorumluluk projeleri yürütmesinin müşterilerin satın alma davranışını etkilemekte olduğu son zamanlarda gerek akademik dünyada gerekse iş dünyasında sıklıkla konu edilmektedir. Bu sebeple son dönemde birçok işletmenin reklam vermek yerine sosyal sorumluluk projeleri ile kamuoyunu bilgilendirmeyi tercih ettiği dikkat çekmektedir.

İşletmeler toplumun bir parçası olarak faaliyet göstermektedir. Toplum ile etkileşim içerisinde olan işletmelerin aynı zamanda topluma hizmet etmeleri gerekmektedir. Bir başka deyişle, işletmeler toplumdan aldıklarını yine topluma vererek toplumsal kalkınmaya katkı sağlamalıdırlar. Bu bağlamda, işletmeler toplumsal meseleleri belirleyerek sosyal sorumluluk projeleri çerçevesinde bu sorunlara çözümler üretmektedirler. İşletmelerin topluma yapmış olduğu bu katkı ise müşteriler tarafından olumlu karşılanmakta, aynı zamanda, müşteriler işletmelere ve bunun yanı sıra işletmelerin ürün ve hizmetlerine de güvenmektedirler. Güven, müşterilerin bir işletmeden en önemli beklentilerinden biridir. Müşteriler, almış olduğu ürüne güvenmenin yanı sıra, ürün ve hizmetini aldığı işletmeye her yönü ile güvenmek istemektedir. Dolayısıyla güven işletmelerin sürdürülebilirliği açısından oldukça önemlidir. Bir başka ifadeyle, sosyal sorumluluk projeleriyle toplumsal meselelere katkı sağlayan işletmelere müşterilerin daha fazla güvenecekleri ve ürün ve hizmetlerini daha fazla tercih edecekleri düşünülmektedir. Alanyazınında, işletmelerin müşterilerine güven veriyor olmasının müşterilerin satın alma niyetini arttırdı̆̆ı görülmektedir. Dolayısıyla, bu çalışmada işletmelerin yapmış oldukları sosyal sorumluluk projelerinin, müşterilerin satın alma niyetleri üzerindeki etkisinde güvenin aracılık rolü incelenecektir.

\section{Literatür Taraması}

\section{Kurumsal Sosyal Sorumluluk}

Günümüzde müşterilerin gerek medya araçlarını kullanarak gerekse internetten faydalanarak bilinçlenmesiyle birlikte herhangi bir ürün ya da hizmet almadan önce sadece ürünün bireysel faydasına odaklanmak yerine aynı zamanda işletmenin paydaşlarına olan duyarlılığını da dikkate almakta oldukları bilinmektedir. Bu sebeple, sadece kâr amacı güden, paydaşlarına katkısı olmayan işletmelerin ayakta kalabilmeleri neredeyse imkânsızlaşmıştır (Eren ve Eker, 2012).

İşletmeler açık sistemde yer almaktadır. Açık sistemler, "çevresinden veya başka sistemlerden enerji, bilgi ve materyal alır, bunları işler ve çeşitli formlarda (mal, hizmet) tekrar çevresine veya başka sistemlere gönderir" (Koçel, 2018). Bir başka deyişle, açık sistemde yer alan işletmelerin çevrelerinden etkilenmelerinin yanı sıra çevrelerini de etkilemektedir. Örneğin, çevresel unsurlarda meydana gelen bir değişime işletmeler hızlıca cevap vermek zorundayken aynı zamanda, çevrenin ihtiyaçlarını da karşılamak zorundadır. Çevreden gelen ihtiyaçları işletmeler çeşitli şekillerde cevaplamaktadır. Bunlardan biri ise kurumsal sosyal sorumluluk projeleridir (Alparaslan ve Aygün, 2013). 


\section{Algılanan Kurumsal Sosyal Sorumluluğun Satın Alma Niyeti Üzerindeki Etkisinde Güvenin Aracılık Rölü Üzerine Bir Araştırma}

Kurumsal sosyal sorumluluk kavramsal olarak yüzyıllar öncesine dayansa da aslında 20. yy'ın son 50 yılını kapsamaktadır (Carroll, 1999). Kurumsal sosyal sorumluluk kavramı ilk kez Bowen'in (1953) "Social Responsibilities of the Businessman" çalışmasıyla literatürde yerini almıştır (Bowen, 2013). Bowen'e kadar sosyal sorumluluk kavramı kurumsal sosyal sorumluluk adı altında değil sosyal sorumluluk olarak ele alınıyordu. Bowen ile birlikte sosyal sorumluk kavramı işletmeler açısından ele alınmıştır. Hatta Bowen 1953 yılında yayınladığı kitabının başlığında iş adamı sözcügüüne yer vermiştir. Bunun nedeni ise o dönem kadınların iş dünyasında pek yer almaması ve resmî yazılarda kabul edilmiyor olmasıdır (Carroll, 1999). Bowen'e göre kurumsal sosyal sorumluluk, iş adamlarının toplumun hedef ve değerleri açısından arzu edilen eylemleri takip etme ve politikalar düzenlemesidir. Bowen'in bir diğer tanımı ise, işletmelerin yürütmüş oldukları iş operasyonlarının etkilerine odaklanarak sosyal değer edinme düşüncesidir (Bowen, 2013).

Bir başka tanıma göre, kurumsal sosyal sorumluluk, sosyal refahı arttırıcı işletmelerin yürütmüş olduğu ihtiyari (isteğe bağl1) kurumsal faaliyetlerdir (Carnahan, 2017). Aynı zamanda kurumsal sosyal sorumluluk, işletmelerin toplum ile kurmuş oldukları ilişki ve işletmelerden etkilenen ve etkileyen gruplara yönelik katkılarıdır (Ayhan, 2009). Bir başka deyişle ise, kurumsal sosyal sorumluluk, örgütlerin herhangi bir yasal baskı ya da zorlama olmadan gönüllülük esasına dayalı olarak paydaşlarının ekonomik, çevresel ve toplumsal sorunlarına katkı sağlamasıdır (Dinçer ve Özdemir, 2013).

Son zamanlarda kurumsal sosyal sorumluluk kavramı hem akademisyenlerin hem de iş dünyasının ilgisini çekmektedir. Bu ilginin odağında işletmelerin paydaşlarının gözündeki değeri arttırması için toplumsal sorunlarla ilgilenme meselesine yönelik eleştiriler ve tartışmalar söz konusudur. İşletmeleri bu konuda eleştirenler öncelikle sosyal sorumluluk faaliyetlerinin esas amacından farklı ve ticari sebepler ile yapıldığını düşünmektedirler. Bu sebeple, kimilerine göre işletmelerin toplumsal meselelerle ilgilenmesi gerekirken, kimileri ise bu görüş̧e karşıdır (Wang, Tong, Takeuchi ve George, 2016). Buna rağmen, müşterilerin büyük bir çoğunluğu işletmelerin tüm paydaşlarının ihtiyaçlarını karşılaması gerektiğini düşünmektedir. Dolayısıyla da, birçok işletme toplumun sağlık, çevre, ekonomi, kalkınma gibi sorunlarına katkı sağlamalıdır görüşünden hareketle, kurumsal sosyal sorumluluk projeleri gerçekleştirmektedir (Avcı ve Akdemir, 2014).

\section{Güven}

Türk Dil Kurumuna göre güven, “çekinme ve kuşku duymadan inanma ve bağlanma duygusudur" (TDK, Aralık, 2018). 1980 yılından bu yana içerisinde farklı boyutları barındıran güven kavramı literatürde farklı perspektiflerde incelenmektedir (Begzadeh ve Nedae, 2017). Güven kavramının tanımı ile yaşanan karmaşa, risk ve güven arasındaki ilişkinin net olmaması ve güvenin öncülleri ve sonuçlarının belirlenmesinde yaşanan sorunlardan dolayı güven kavramı araştırmacılar tarafından farklı şekillerde tanımlanmıştır (Caldwell, 2014; Mayer, Davis ve Schoorman, 1995). Alanyazında verilen tanımlar farklı unsurlar barındırsa da (Mayer ve diğerleri, 1995) çoğu tanımda üç unsuru görmek mümkündür: risk alma eğilimi, iyimserlik ve doğallık (içtenlik) (Cho ve Song, 2017).

Bunun yanı sıra, güven güvenilirlik, öngörülebilirlik, kapasite, yetkinlik, uzmanlık, iyi niyet, açık yönetim, kabul ve benzeri anlamları içerir (Begzadeh ve Nedae, 2017). Güven, sosyal belirsizlik ve risk içeren tüm ticari alışverişlerde önemli bir rol oynamaktadır (Mayer ve diğerleri, 1995). Morgan ve Hunt (1994: 23) müşterinin işletmeye duyduğu güveni müşterinin 
karşı tarafın güvenilir ve ahlaklı davranacağından emin olması olarak tanımlamıştır. Yazarlara göre güven, işletmeler ve müşteriler arasında uzun dönemli bir ilişki oluşmasını ve bu ilişkinin devamını sağladığı için işletmeler için son derece önemlidir. Aynı zamanda işletmeler, müşteriler tarafından güvenilir diye algılandıklarında toplum tarafından da desteklenir (Eren ve Eker, 2012). Bu bağlamda, müşteri güveni, "ürün veya hizmet sağlayıcının müşterilerin uzun vadeli çıkarlarına hizmet edecek şekilde davranmaya yönelik inancı"dır (Lin, Chen, Chiu ve Lee, 2011). Müşterinin işletmeye duyduğu güveni zihinsel bir değerlendirme olarak kabul eden Morgan ve Hunt (1994) güven ile davranışsal eğilimler arasında bir ilişki olduğunu ve bunun incelenmesi gerektiğini belirtmiştir. Bu bakış açısından yola çıkarak, marka güveni kavramını oluşturan Delgado-Ballester ve Munuera-Aleman (2001) marka ve müşteri arasında uzun dönemli ilişkide güvenin önemli rolüne dikkat çekmiş ve işletmelerin yaptığı tüm hareketlerin müşteriler tarafından değerlendirilmesi sonucunda oluşan güvenin marka bağlılığını oluşturduğu sonucuna varmıştır. Bunun yanı sıra, güven müşteri ilişkileri yönetimi açısından ön koşul olduğu gibi satın alma niyetinin de öncülüdür (Lin ve diğerleri, 2011).

\section{Satın Alma Niyeti}

Satın alma niyeti, müşterilerin belirli bir ürün ya da hizmeti alma olasılığıdır (Chang ve Wildt, 1994). Satın alma niyeti gerçek satın almayı değil bir sonraki satın alma ve karar verme durumunda müşterinin ürünü veya hizmeti alma konusundaki düşüncesini belirtmektedir; ancak literatürde satın alma yerine ve ileride gerçekleşmesi beklenen satın almayı göstermesi açısından sıklıkla kullanılmaktadır (Jamieson ve Bass, 1989; Kalwani ve Silk, 1982; Sun ve Morwitz, 2010: 356). Genel olarak müşterinin bir ürün ya da hizmet için biçtiği değer yüksek ise müşterinin satın alma niyetinin de yüksek olacağı düşünülmektedir (Chang ve Wildt, 1994).

\section{Yöntem}

\section{Araştırmanın Amacı ve Kapsamı}

Araştırmanın amacı algılanan kurumsal sosyal sorumluluğun satın alma niyeti üzerindeki etkisinde güvenin aracılık rolünü ortaya koyarak alanyazına katkı sağlamaktır. Araştırmada ele alınan kavramlar ve kavramların test edildiği işletme dikkate alındığında, araştırmanın değişkenlerinin farklı işletmelerde çalışan, farklı kültürlerden gelen kişilerce cevaplanması araştırma sonuçlarını çeşitlendireceği düşünülmüştür. Bu görüşten hareketle araştırma bir vakıf üniversitesinde yüksek lisans eğitimi alan kişilerle gerçekleştirilmiştir.

Bu bağlamda bahsi geçen üniversitede 2018 yılında yüksek lisans programina 722 öğrencinin kayıtlı olduğu bilgisi edinilmiştir. Ana kütle üzerinden örnek kütle hesabına göre 772 örnek büyüklügünün \%95 güven sinırları içerisinde ve \%5 anlamlılık düzeyinde 251 olduğu hesaplanmıştır. Anket yöntemi kullanılan bu çalışmada veriler araştırmacılar tarafından sınıf ortamında dağıtılarak elde edilmiştir. Araştırma kapsamına alınan katılımcı sayısı ise 313'tür.

\section{Araştırmanın Modeli ve Hipotezleri}

Alanyazında belirtildiği üzere, kurumsal sosyal sorumluluk ile güven arasında ilişki olduğu görülmektedir. Müşterilerin, kurumsal sosyal sorumluluk projelerini yürüten işletmelere daha fazla güvendiği literatürde belirtilmiştir. Aynı zamanda, müşteriler bir örgüte ya da markaya veyahut bir ürüne güvendiklerinde o örgütün, markanın ya da ürünün sosyal açıdan sorumlu olduğunu düşünmektedir (Afridi, Gul, Haider ve Batool, 2018; Ammar, Naoui ve Zaiem 2015; Ko, Rhee, Kim ve Kim, 2014; Lin ve diğerleri, 2011; Perrini, Castaldo, Misani ve 


\section{Algılanan Kurumsal Sosyal Sorumluluğun Satın Alma Niyeti Üzerindeki Etkisinde Güvenin Aracılık Rölü Üzerine Bir Araştırma}

Tencati, 2010; Saat ve Selamat, 2014; Vlachos, Tsamakos, Vrechopoulos ve Avramidis, 2009; Xie, 2014). Bu güvenin en büyük sebeplerinden biri Johnson-George ve Swap (1982)'a göre müşterilerin risk almak istememeleridir. Mayer ve diğerleri (1995)'e göre bir işletmenin sadece kâr amacı ile değil müşterinin çıkarlarını düşünerek hareket edeceğine inanılması güvenin en önemli unsurlarından biridir. Bu sebeple kurumsal sosyal sorumluluk faaliyetlerinin müşterilerin risk algısını etkileyeceği ve işletmenin sadece kâr amacı değil topluma fayda amacını da güttügünü düşünen müşterilere olumlu yönde tesir edeceği ve güven uyandıracağı düşünülebilir. Bunun yanında müşterinin işletmeye duyduğu güvenin satın alma üzerinde etkili olduğu görülmüştür (Gefen ve Straub, 2004).

Ayrıca, bir kurumun faaliyet, ürün ve davranışlarının müşteriler tarafından sosyal sorumlu olarak algılandığı durumda müşterilerin daha fazla ödemeye bile razı oldukları bilinmektedir (Auger, Burke, Devinney ve Louviere, 2003). Aynı zamanda, Murray ve Vogel (1997) kurumsal sosyal sorumluluk faaliyetleri ile satın alma niyeti arasında olumlu bir ilişki olduğunu tespit etmiştir.

Bu bağlamda, bu çalışmanın araştırma modeli algılanan sosyal sorumluluğun satın alma niyeti üzerindeki etkisinde güvenin aracılık rolü olabileceği görüşünden hareketle geliştirilmiş olup Şekil-1'de gösterilmiştir.

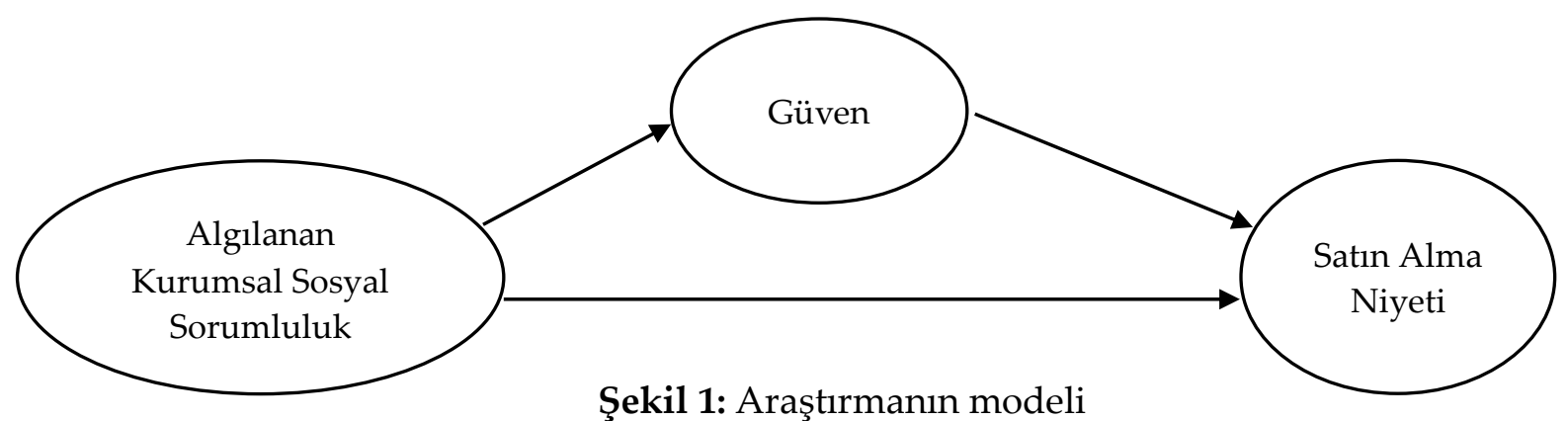

Araştırmanın amacı doğrultusunda aşağıdaki hipotez kurulmuştur:

$\mathrm{H}_{1}$ : Müşterilerin kurumsal sosyal sorumluluk algılarının satın alma niyeti üzerindeki etkisinde güvenin aracılık rolü vardır.

\section{Değişkenlere İlişkin Ölçme Araçları}

Çalışmada kullanılan ölçekler, detaylı bir literatür taramasından sonra belirlenmiş olup ulusal ve uluslararası yazında geçerliliği ve güvenilirliği kanıtlanmış ölçekler kullanılmıştır. Anketi cevaplayanlar öncelikle bilinen otomotiv firmasını düşünerek, bu şirkete yönelik kurumsal sosyal sorumluluk ve güven algıları ve satın alma niyetlerini değerlendirmişlerdir.

Bu bağlamda algılanan kurumsal sosyal sorumluluk ölçeği olarak, Lin ve diğerleri (2011) tarafından geliştirilen 6 ifade ve tek boyuttan oluşan ölçek kullanılmıştır. Lin ve diğerleri (2011) algılanan kurumsal sosyal sorumluluk ölçeğini Curra's-Pe'rez ve diğerleri (2009) tarafından geliştirilen ölçekten esinlenerek geliştirmişlerdir.

Güveni ölçmek için yine Lin ve diğerleri (2011) tarafından geliştirilen 5 ifade ve tek boyuttan oluşan ölçek kullanılmıştır. Lin ve diğerleri (2011) güven ölçeğini Sirdeshmukh vd. (2002) tarafından geliştirilen ölçekten esinlenerek geliştirmişlerdir.

Satın alma niyetini ölçmek için ise Yoo ve Donthu (2001) tarafından geliştirilen 4 ifade ve tek boyuttan oluşan ölçek kullanılmıştır. 
Anket formu, 5'li Likert ölçeğine göre derecelendirilmiş ve derecelendirmeler; Kesinlikle Katılmıyorum (1), Katılmıyorum (2), Kararsızım (3), Katılıyorum (4), Kesinlikle Katılıyorum (5) şeklinde sıralanmıştır.

Demografik soruların oluşturduğu ikinci bölümde ise katılımcıların cinsiyet, medeni durum, yaş ve aylık gelirlerini belirlemeye yönelik ifadeler yer almaktadır.

\section{Bulgular}

\section{Demografik Özelliklere Yönelik Bulgular}

Araştırma kapsamına alınan 313 katılımcının demografik özelliklerinin yüzde dağılımı şu şekildedir: katılımcıların \%55,8'i kadın, \%44,2' si erkektir. Katılımcıların \%27,2'si evli, \%72,8'i ise bekârdır. Ayrıca katılımcıların ortalama yaşının 28,7 olduğu, standart sapması 7 olan katılımcıların yaşının 19 ile 52 arasında değiştiği saptanmıştır. Katılımcıların \%41'i 3000€ ve altı, \%30'u 30001€-5000€ arasında, \%29'u 50001€ ve üzeri aylık gelire sahip olduklarını belirtmişlerdir.

\section{Araştırmanın Değişkenlerine İlişkin Bulgular, Faktör ve Güvenilirlik Analizleri}

Araştırmada kullanılan ölçeklerde yer alan ifadelere ilişkin ortalama ve standart sapma değerleri, faktör ve güvenilirlik analizlerine yönelik bulgular Tablo 1'de gösterilmektedir.

Faktör analizleri sonucunda algılanan kurumsal sosyal sorumluluk ölçeğinin KMO değeri 0,96, Barlett testi 0,000; güven ölçeğinin KMO değeri 0,98, Barlett testi 0,000; satın alma niyeti ölçeğinin KMO değeri 0,76, Barlett testi 0,000'dır. Bu değerler dikkate alındığında, eldeki veri grubunun faktör analizi için uygun olduğu görülmüştür (Durmuş, 2011). Açımlayıcı faktör analizi sonuçları yine Tablo 1'de yer almaktadır. Algılanan kurumsal sosyal sorumluluk ölçeğinin açıkladığı toplam varyans \%76; güven ölçeğinin \%71; satın alma niyeti ölçeğinin ise \%71'dir. Ayrıca, Tablo 1'de de görüleceği üzere, algilanan kurumsal sosyal sorumluluk ölçeğinin Cronbach Alpha güvenilirlik katsayısı 0,92; güven ölçeğinin 0,861; satın alma niyeti ölçeğinin ise 0,862'dir. Bu değerler, tüm ölçeklerin oldukça güvenilir olduğunu göstermektedir (Cronbach, 1951: 328).

Elde edilen bulgular doğrultusunda AMOS 22 kullanılarak doğrulayıcı faktör analizi ve yapısal eşitlik modeli ile analizlere devam edilmiştir. Yapılan analizde doğrulayıcı faktör analizi model uyumunun iyi seviyede olduğu belirlenmiş olup değerler şu şekildedir: $\mathrm{CFI}=0,960 ; \mathrm{TFI}=0,961 ; \mathrm{RMSEA}=0,083$. Doğrulayıcı faktör analizi sonuçları yine Tablo 1'de verilmiştir. Tablo 1'de de görüldüğü üzere, açımlayıcı ve doğrulayıcı faktör analizi faktör yükleri arasında belirgin bir fark bulunmamakta ve değişkenleri oluşturan sorular, dolayısıyla kullanılan ölçekler açısından bir sorun bulunmamaktadır.

Bu sebeple uygulanan faktör ve güvenilirlik analizleri sonucunda algılanan kurumsal sosyal sorumluluk ölçeği orijinal ölçekteki gibi 6 ifadeli tek boyutlu, güven ölçeği orijinal ölçekteki gibi 5 ifadeli tek boyutlu, satın alma niyeti ölçeği orijinal ölçekte olduğu gibi 4 ifadeli ve tek boyutlu bir yapı oluşturmuş ve değişkenler arası ilişkilerin analizine geçilmiştir. 
Algılanan Kurumsal Sosyal Sorumluluğun Satın Alma Niyeti Üzerindeki Etkisinde

Güvenin Aracılık Rölü Üzerine Bir Araştırma

Tablo 1. Ortalama, Standart Sapma, Faktör ve Güvenilirlik Analizleri Sonuçları

\begin{tabular}{|c|c|c|c|c|c|c|c|c|}
\hline DEĞİŞKENLER & İFADELER & ORTALAMA & $\begin{array}{l}\text { STANDART } \\
\text { SAPMA }\end{array}$ & $\begin{array}{l}\text { AÇIMLAYICI } \\
\text { FAKTÖR } \\
\text { ANALİİ } \\
\text { YÜKLERİ } \\
\end{array}$ & $\begin{array}{l}\text { AÇIKLANAN } \\
\text { VARYANS }\end{array}$ & GÜVENILİRLİK & $\begin{array}{c}\text { DOĞRULAYICI } \\
\text { FAKTÖR } \\
\text { ANALİZI } \\
\text { YÜKLERİ } \\
\end{array}$ & AVE \\
\hline \multirow{6}{*}{$\begin{array}{l}\text { KURUMSAL } \\
\text { SOSYAL } \\
\text { SORUMLULUK }\end{array}$} & xxxx sosyal sorumluluk faaliyetlerini destekler. & 3,11 & 0,96 & 0,902 & \multirow{6}{*}{$\% 76$} & \multirow{6}{*}{0,92} & 0,702 & \multirow{6}{*}{$\% 69$} \\
\hline & xxxx çevre ile ilgili sorumlu davranır. & 2,96 & 1,17 & 0,901 & & & 0,851 & \\
\hline & xxxx çevre sorunlarını farkındadır. & 2,89 & 1,11 & 0,894 & & & 0,832 & \\
\hline & xxxx sosyal sorumluluklarını yerine getirir & 3,11 & 0,98 & 0,902 & & & 0,854 & \\
\hline & xxxx kazandıklarını topluma geri verir. & 2,88 & 1,09 & 0,894 & & & 0,855 & \\
\hline & xxxx sosyal sorumlu bir şekilde davranır. & 3,01 & 1,05 & 0,765 & & & 0,891 & \\
\hline \multirow{5}{*}{ GÜVEN } & xxxx'in yaptıklarında yetkin olduğuna inanıyorum. & 3,70 & 0,97 & 0,888 & \multirow{5}{*}{$\% 71$} & \multirow{5}{*}{0,86} & 0,785 & \multirow{5}{*}{$\% 57$} \\
\hline & Genel olarak xxxx'in güvenilir olduğunu hissediyorum. & 3,79 & 0,99 & 0,840 & & & 0,78 & \\
\hline & Genel olarak xxxx'in dürüst olduğunu hissediyorum. & 3,65 & 0,99 & 0,850 & & & 0,810 & \\
\hline & $\begin{array}{l}\text { Genel olarak xxxx'in müşterilerine duyarlı olduğunu } \\
\text { hissediyorum. }\end{array}$ & 3,51 & 0,99 & 0,824 & & & 0,763 & \\
\hline & $\begin{array}{l}\text { Genel olarak xxxx'in sorunlara anlayışla karşılık vereceğini } \\
\text { hissediyorum. }\end{array}$ & 3,50 & 0,98 & 0,894 & & & 0,699 & \\
\hline \multirow{4}{*}{$\begin{array}{l}\text { SATIN ALMA } \\
\text { NIYETI }\end{array}$} & $\begin{array}{l}\text { Eğer satın alma olanağı verilse xxxx markasından araba satın } \\
\text { alırım. }\end{array}$ & 3,96 & 1,13 & 0,851 & \multirow{4}{*}{$\% 71$} & \multirow{4}{*}{0,86} & 0,916 & \multirow{4}{*}{$\% 58$} \\
\hline & $\begin{array}{l}\text { Eğer satın alma olanağ verilse gelecekte xxxx markasından } \\
\text { araba satın alırım. }\end{array}$ & 3,88 & 1,10 & 0,851 & & & 0,969 & \\
\hline & $\begin{array}{l}\text { Muhtemelen yakın gelecekte xxxx markasından araba satın } \\
\text { alacağım. }\end{array}$ & 2,78 & 1,22 & 0,833 & & & 0,511 & \\
\hline & $\begin{array}{l}\text { Yakın gelecekte xxxx markasından araba satın alırım diye } \\
\text { düşünüyorum. }\end{array}$ & 2,93 & 1,23 & 0,833 & & & 0,509 & \\
\hline
\end{tabular}




\section{Değişkenler Arası İlişkilerin Araştırılması}

Değişkenler arasındaki ilişkiye geçilirken öncelikle korelasyon analizi yapılmıştır. Bu analizin sonucunda "algilanan kurumsal sosyal sorumluluk" ve "satın alma niyeti" arasında 0,322 $(\mathrm{p}=0,000<0,01)$, "algılanan kurumsal sosyal sorumluluk" ve "güven" arasinda 0,470 $(\mathrm{p}=0,000<0,01)$ ve "güven" ile "satın alma niyeti" arasında $0,614(\mathrm{p}=0,000<0,01)$ değerlerinde korelasyon tespit edilmiştir. Edinilen bulgular değişkenler arasındaki ilişkileri destekler yeterli seviyededir. Dolayısıyla araştırmanın modelinde belirtilen şekilde yapısal eşitlik modeli kurulmuş ve eldeki veri ile test edilmiştir.

Kurumsal Sosyal Sorumluluk Algısının Satın Alma Niyeti Üzerindeki Etkisinde Güvenin Aracılık Rolü

Alanyazında da belirtildiği üzere, müşterilerin kurumsal sosyal sorumluluk algılarının satın alma niyeti üzerindeki etkisinde güvenin aracılık rolü olabileceği düşüncesiyle araştırmanın ana hipotezi şu şekilde kurulmuştur;

$\mathrm{H}_{1}$ : Müşterilerin kurumsal sosyal sorumluluk algılarının satın alma niyeti üzerindeki etkisinde güvenin aracılık rolü vardır.

Tablo 2. H1 Hipotez Sonuçları

\begin{tabular}{lccc}
\hline Değişkenler Arası İlişki & $\begin{array}{c}\text { Aracı ile } \\
\text { Direkt }\end{array}$ & $\begin{array}{c}\text { Aracı ile İndirekt } \\
\text { (Bootstrapping) }\end{array}$ & CR \\
\hline $\begin{array}{l}\text { Algılanan Kurumsal Sosyal Sorumluluk } \rightarrow \\
\text { Satın Alma Niyeti }\end{array}$ & $0,102^{*}$ & & 2,013 \\
$\begin{array}{l}\text { Algılanan Kurumsal Sosyal Sorumluluk } \rightarrow \\
\text { Güven }\end{array}$ & $0,507^{*}$ & & 7,36 \\
Güven $\rightarrow$ Satın Alma Niyeti & $0,797^{*}$ & \\
$\begin{array}{l}\text { Algilanan Kurumsal Sosyal Sorumluluk } \rightarrow \\
\text { Güven } \rightarrow \text { Satın Alma Niyeti }\end{array}$ & 0,31 & $0,404^{*}$ & 11,154 \\
$*$ p $<0.01$ seviyesinde anlamlı & $(0,704)$ & & 0,379 \\
& & & \\
\hline
\end{tabular}

Tablo 2'de görüldüğü üzere, araştırmanın hipotezini test etmek amacı ile yapılan yapısal eşitlik modeli analizi $\left(\chi^{2} / \mathrm{df}=3,13\right.$; $\mathrm{CFI}=0,962 ; \mathrm{TFI}=0,951$; RMSEA=0,073) sonucuna göre, "algılanan kurumsal sosyal sorumluluk"un "satın alma niyeti" üzerinde kısıtlı ancak anlamlı bir etkisi bulunmaktadır $(0,102 \mathrm{p}=0,000<0,01)$. Yine aynı şekilde yapısal eşitlik modeli çıktısında verilen direkt ilişki verilerine göre "algılanan kurumsal sosyal sorumluluk"un "güven" üzerinde anlamlı bir etkisi $(0,507 \mathrm{p}=0,000<0,01)$ ve "güven"in "satın alma niyeti" üzerinde anlamlı bir etkisi $(0,797 \mathrm{p}=0,000<0,01)$ olduğu görülmektedir.

Aracılık etkisi dikkate alındığında ise bootstrapping ile yapılan analizde direkt ilişki olarak anlamlı olan "algılanan kurumsal sosyal sorumluluk" ve "satın alma niyeti" arasındaki ilişkinin istatistiksel olarak anlamsız bir değere dönüştüğü $(p=0,704>0,1)$ ancak "güven" üzerinden endirekt olarak güçlenerek devam ettiği görülmektedir $(0,404 p=0,000>0,01)$. Bu şartlar altında güvenin algılanan kurumsal sosyal sorumluluk ve satın alma niyeti arasındaki ilişkide tam aracılık etkisi söz konusu olup $\mathrm{H}_{1}$ hipotezi kabul edilmiştir. 


\section{Tartışma, Sonuç ve Öneriler}

$\mathrm{Bu}$ çalışmanın amacı algılanan kurumsal sosyal sorumluluğun satın alma niyeti üzerindeki etkisinde güvenin rolünün belirlenmesidir. Bu amaçla İstanbul'da bir vakıf üniversitesinde yüksek lisans eğitimi alan 313 kişiden veri toplanmıştır.

Araştırma sonuçlarına göre, algılanan kurumsal sosyal sorumluluğun satın alma niyeti üzerindeki etkisinin 0,102 olduğu tespit edilmiştir. Bu sonuç dikkate alındığında, algılanan kurumsal sosyal sorumluluğun satın alma niyeti üzerinde çok düşük düzeyde etkisi olduğu sonucuna varılmıştır. Bir başka deyişle, örneklem dikkate alındığında, müşterilerin herhangi bir ürün ya da hizmeti alma kararı verdiklerinde o işletmenin yapmış olduğu sosyal sorumluluk projelerini pek de dikkate almadığ görülmektedir. Bu bağlamda, müşterilerin satın alma niyetlerini etkileyen başka faktörlerin olduğu görülmektedir. Bu bulgular daha önce literatürde farklı bağlamlarda test edilmiş olan algılanan kurumsal sosyal sorumluluk ve satın alma arasındaki ilişkiyi (Auger ve diğerleri, 2003; Amoroso ve Roman, 2015; Murray ve Vogel, 1997) destekler ve ilerletir yöndedir.

Yapılan analizlere göre araştırmanın bir diğer sonucu ise algılanan kurumsal sosyal sorumluluğun güven üzerindeki etkisinin 0,507 olduğudur. Bu sonuç değerlendirildiğinde bahsi geçen kavramlar arasında orta düzeyde ilişki olduğu görülmektedir. Bir başka ifadeyle, işletmelerin yapmış oldukları sosyal sorumluluk projeleri, müşterilerin güvenini arttırmaktadır. Dolayısıyla sosyal sorumluluk projelerinde yer alan işletmeler, müşteriler tarafından güvenilir olarak değerlendirilmektedir. Bu bulgular daha önce yapılan çalışmaları (Afridi ve diğerleri 2018; Ammar ve diğerleri, 2015; Ko ve diğerleri, 2014; Lin ve diğerleri, 2011; Perrini ve diğerleri, 2010; Saat ve Selamat, 2014; Vlachos ve diğerleri, 2009; Xie, 2014) destekler niteliktedir.

Araştırmanın bir diğer bulgusu olarak güvenin satın alma niyeti üzerindeki etkisinin 0,797 olduğu bulunmuştur. Bu değer dikkate alındığında, müşterilerin satın alma niyetini işletmeye olan güvenlerinin yüksek düzeyde etkilediği görülmektedir. Bir başka ifadeyle, müşteriler bir ürün ya da hizmeti almak istediklerinde güvendikleri işletmeden ürün ve hizmetler satın almayı tercih ettikleri söylenebilir. Gefen ve Straub (2004), Lin ve Lu (2010) ve Turgut (2014) taraflarından yapılan çalışmalar bu bulguları destekler niteliktedir.

Araştırmanın hipotezi doğrultusunda elde edilen sonucu ise güvenin, algılanan kurumsal sosyal sorumluluk ve satın alma niyeti arasındaki ilişkiyi $(p=0,704)$ anlamsız yöne çevirmesi sebebi ile tam aracı değişken görevi görmekte olduğu ve bu modelin satın alma niyetinin \%40'ını açıkladığıdır. Bu bağlamda araştırmanın hipotezi kabul edilmiştir. Bu sonuç, işletmelerin yapmış oldukları sosyal sorumluluk projeleriyle müşterilerinin güvenini kazandığı, bu durumun da müşterilerin satın alma davranışlarını etkilediğini göstermektedir. Dolayısıyla, işletmeler sosyal sorumluluk projeleri gerçekleştirerek müşterilerinin güvenini kazanabilir ve böylelikle müşterilerin satın alma niyetleri etkiliyebilir. Kısaca, araştırma sonucunda, algılanan sosyal sorumluluğun müşterilerin ürün ya da hizmetleri satın almalarındaki etkisinde özellikle duydukları güvenin çok önemli olduğu görülmüştür. Araştırma yapılırken, katılımcılara sunulan otomotiv şirketi değerlendirildiğinde, Ülkemizde müşteri nezdinde güven denildiğinde akla gelen ilk markalardan biri olması bu sonucu destekler niteliktedir. Bu sonuç doğrultusunda, işletmelerin sadece sosyal sorumluluk faaliyetlerinde bulunmalarının satın alma niyetini olumlu yönde etkilemekte yeterli olmadığı, aynı zamanda işletmelerin bu faaliyetlerin müşteride güven yaratıp yaratmadığını da ele 
almaları gerektiği ve esasen müşterilerin ürün ya da hizmetlerini satın almayı düşündükleri işletmeye güvenmelerinin satın alma niyetini etkilediği görülmektedir.

Bunun yanı sıra, güvenin en önemli öncüllerinden biri karşıdakinin tutarlı ve kişinin menfaatlerini dikkate alır şekilde davranacağına olan inançtır. Bu sebeple daha önce müşteride oluşturulmuş olan imaj ve tutum ile örtüşen sosyal sorumluluk projelerinin, müşterilerde daha fazla güven uyandıracağı ve bu işletmenin ürün ya da hizmetini satın alma niyetlerini olumlu yönde etkileyeceği öngörülebilir.

Bu çalışma, sosyal bilimlerde yapılan tüm diğer çalışmalarda olduğu gibi çeşitli kısıtlara sahiptir. Örneklem bu çalışmanın en büyük kısıtıdır. Bu nedenle sonuçlar hakkında genelleme yapılabilmesi için farklı bir örneklem kullanılarak veri toplanması önerilir. Bu çalışmanın otomotiv sektöründe yapılmış olması araştırmanın bir diğer kısıtıdır. İleride yapılacak araştırmaların farklı kurum veya sektörlerde yapılması faydalı olacaktır. Ayrıca güven kavramının farklı kültürler için farklı anlamlar içerdiği göz önünde bulundurularak (Schoorman, Mayer ve Davis, 2007), farklı kültür ya da alt kültürler ile araştırmanın tekrarlanması da literatüre katkı sağlayacaktır. Bunun yanı sıra şirket/kurum imajı, şirket/kurum itibarı, marka çekiciliği, marka tanınırlı̆̆ı, müşteri memnuniyeti, müşteri sadakati gibi konuların araştırmacılar tarafından incelenmesi sosyal bilimlere katkı sağlayacaktır.

\section{Kaynakça}

Afridi, S., Gul, S., Haider, M. \& Batool, S. (2018), “Mediating effect of customers' trust between the association of corporate social responsibility and customers' loyalty: an empirical investigation from telecom sector", Pakistan Journal of Commerce \& Social Sciences, 12(1), 214228.

Alparslan, A. \& Aygün, M. (2013), "Kurumsal sosyal sorumluluk ve firma performansı", Süleyman Demirel Üniversitesi İktisadi ve İdari Bilimler Fakültesi Dergisi, 18(1), 435-448.

Amoroso, D. L. \& Roman, F. (2015), “Corporate social responsibility and purchase intention: the roles of loyalty, advocacy and quality of life in the Philippines", The International Journal of Management, 4(1), 25-41.

Ammar, H. B., Naoui, F.B. \& Zaiem, I. (2015), “The influence of the perceptions of corporate social responsibility on trust toward the brand", International Journal of Management, Accounting and Economics, 2(6), 499-516.

Auger, P., Burke, P., Devinney, T. M. \& Louviere, J.J. (2003), “What will consumers pay for social product features?", Journal of Business Ethics, 42(3), 281-304.

Avcl, N. \& Akdemir, İ. (2014), “Konaklama işletmelerinde kurumsal sosyal sorumluluk algısının iş doyumu üzerine etkisi", Ege Academic Review, 14(1) 125-135.

Ayhan, B. (2009), "Siyasal iktisat ve kurumsal sosyal sorumluluk”, Yönetim Araştırmaları Dergisi, 9(2), 173-187.

Begzadeh, S.\& Nedaei, M. (2017), “The relationship between servant leadership with organizational trust and employee empowerment in the social security organization of ardabil", International Journal of Management, Accounting E Economics, 4(3), 270-281.

Bowen, H. R. (2013), Social responsibility of the businessman. University of IOWA Press:Iowa City. 


\section{Algılanan Kurumsal Sosyal Sorumluluğun Satın Alma Niyeti Üzerindeki Etkisinde Güvenin Aracılık Rölü Üzerine Bir Araştırma}

Caldwell, J. (2014), "Interactional justice dimensions and organizational trust: an investigation into the moderating effects of stress and a three-way interaction", Journal of Organizational Culture, Communications $\mathcal{E}$ Conflict, 18(2), 25-43.

Carnahan, S., Kryscynski, D. \& Olson, D. (2017), “When does corporate social responsibility reduce employee turnover? evidence from attorneys before and after 9/11", Academy of Management Journal, 60(5), 1932-1962.

Carroll, A. B. (1999), “Corporate social responsibility: evolution of a definitional construct”, Business \& Society, 38(3), 268-295.

Chang, T-Z \& Wildt, A. R. (1994), "Price, product information, and purchase intention: an empirical study", Journal of the Academy of Marketing Science, 22(1), 16-27.

Cho, Y. J. \& Song, H. J. (2017), “Determinants of turnover intention of social workers: effects of emotional labor and organizational trust", Public Personnel Management, 46(1). 41-65.

Cronbach, L. J. (1951). "Coefficient alpha and the internal structure of tests" Psychometrika, 16(3), 297-334.

Curra's-pe'rez, R, Bigne'-alcan iz, E. \& Alvarado-Herrera, A. (2009), “The role of selfdefinitional principles in consumer identification with a socially responsible company", Journal of Business Ethics. 89(4), 547-564.

Delgado-Ballester, E. \& Munuera-Alemán, J. L. (2001), “Brand trust in the context of consumer loyalty", European Journal of Marketing, 35(11/12), 1238-1258.

Dinçer, M. A. M. \& Özdemir, Y. (2013), “Kurumsal sosyal sorumluluk uygulamaları ve eşbiçimlilik: on büyük türk holdingi üzerine vaka çalışması", Afyon Kocatepe Üniversitesi İktisadi ve İdari Bilimler Fakültesi Dergisi, 15(2), 31-66.

Durmuş, B., Yurtkuru, S. \& Çinko. M. (2011). Sosyal bilimlerde spss'le veri analizi. 4. Baskı. Beta Yayıncilık: İstanbul.

Eren, S. S. \& Eker, S. (2012), “Kurumsal sosyal sorumluluk algısının marka imajı, algılanan değer, müşteri tatmini ve marka sadakatine etkisi üzerine bir saha araştırması: $\mathrm{x}$ markası örneği", Süleyman Demirel Üniversitesi İktisadi ve İdari Bilimler Fakültesi Dergisi, 17(2), 451472.

Gefen, D. \& STRAUB, D. W. (2004), "Consumer trust in b2c e-commerce and the importance of social presence: experiments in e-products and e-Services", Omega, 32(6), 407-424.

Jamieson, L. F. \& Bass, F. M. (1989), “Adjusting stated intention measures to predict trial purchase of new products: a comparison of models and methods", Journal of Marketing Research, 26(3), 336-345.

Johnson-George, C. \& Swap, W. C. (1982), "Measurement of specific interpersonal trust: construction and validation of a scale to assess trust in a specific other", Journal of Personality and Social Psychology, 43(6), 1306-1317.

Kalwani, M. U. \& Silk, A. J. (1982), “On the reliability and predictive validity of purchase intention measures", Marketing Science, 1(3), 243-286. 
Ko, Y. J., Rhee, Y. J., Kim, Y. K. \& Kim, T. (2014), “Perceived corporate social responsibility and donor behavior in college athletics: the mediating effects of trust and commitment", Sport Marketing Quarterly, 23(2), 73-82.

Koçel, T. (2018). İşletme yöneticiliği. Beta Yayıncılık: İstanbul.

Lin, C.-P., Chen, S-C., Chiu, C-K. \& Lee, W-Y. (2011), "Understanding purchase intention during product-harm crises: moderating effects of perceived corporate ability and corporate social responsibility", Journal of Business Ethics, 102(3), 455.

Lin, L-Y \& Lu, C-Y. (2010), "The influence of corporate image, relationship marketing, and trust on purchase intention: the moderating effects of word-of-mouth", Tourism Review, 65(3), 16-34.

Mayer, R., Davis, J. H. \& Schoorman, F. D. (1995), “An integrative model of organizational trust", Academy of Management Review, 20(3), 709-734.

Morgan, R. M. \& Hunt, S. (1994), “The commitment-trust theory of relationship marketing", The Journal of Marketing, 58(3), 20-38.

Murray, K. B. \& Vogel, C. M. (1997), “Using a hierarchy-of-effects approach to gauge the effectiveness of corporate social responsibility to generate goodwill toward the firm: financial versus nonfinancial impacts", Journal of Business Research, 38(2), 141-159.

Perrini, F., Castaldo, S., Misani, N. \& Tencati, A. (2010), “The impact of corporate social responsibility associations on trust in organic products marketed by mainstream retailers: a study of Italian consumers", Business Strategy and the Environment, 19(8), 512-526.

Saat, R. M. \& Selamat, M. H. (2014), “The impact of corporate social responsibility information richness on trust", Issues in Social and Environmental Accounting, 8(2), 67-81.

Schoorman, F. D, Mayer, R. C. \& Davis, J. H. (2007), “An integrative model of organizational trust: past, present, and future", 32(2), 344-354.

Sirdeshmukh, D. J. S. \& Sabol, B. (2002), “Consumer trust, value, and loyalty in relational exchanges", Journal of Marketing, 66(1), 15-37.

Sun, B. \& Morwitz, V. G. (2010), "Stated intentions and purchase behavior: a unified model", International Journal of Research in Marketing, 27(4), 356-366.

Turgut, M. Ü. (2014), Marka sevgisinin marka güveni, olumsuz bilgiye karşı direnç ve tekrar satın alma niyeti çerçevesinde incelenmesi, (Yüksek Lisans Tezi, , Hacettepe Üniversitesi, Ankara). Erişim adresi: http://tez2.yok.gov.tr/

Yoo, B. \& Donthu, N. (2001), "Developing a scale to measure the perceived quality of an internet shopping site (SITEQUAL)", Quarterly Journal of Electronic Commerce, 2(1), 31-47.

Vlachos, P. A., Tsamakos, A., Vrechopoulos, A. P. \& Avramidis, P. (2009), “Corporate social responsibility: attributions, loyalty, and the mediating role of Trust", Journal of the Academy of Marketing Science, 3(2), 170-180.

Wang, H., Tong, L., Takeuchi, R. \& George, G. (2016), “Corporate social responsibility: an overview and new research directions: thematic issue on corporate social responsibility", Academy of Management Journal, 59(2), 534-544. 
Xie, Y.(2014), "The effects of corporate ability and corporate social responsibility on winning customer support: an integrative examination of the roles of satisfaction, trust and 1dentification", Global Economic Review, 43(1), 73-92.

http://www.tdk.gov.tr/index.php?option=com_gts\&kelime=G\%C3\%9CVEN Erişim Tarihi: 10 Aralık 2018. 